\title{
The Real Exchange Rate Misalignment: Application of Behavioral Equilibrium Exchange Rate BEER to Morocco1980Q1-2012Q4
}

\author{
Hind Lebdaoui ${ }^{1}$ \\ ${ }^{1}$ School of finance, Shanghai University of Finance \& Economics, Shanghai, China \\ Correspondence: Hind Lebdaoui, School of finance, Shanghai University of Finance \& Economics, Shanghai \\ 200083, China. Tel: 86-134-0218-8777. E-mail: hind.encg@gmail.com
}

\author{
Received: July 31, $2013 \quad$ Accepted: August 15, $2013 \quad$ Online Published: September 26, 2013 \\ doi:10.5539/ijef.v5n10p36 URL: http://dx.doi.org/10.5539/ijef.v5n10p36
}

\begin{abstract}
This study is an attempt to estimate the behavioral equilibrium exchange rate in Morocco. Since the equilibrium value is unobservable, we use a set of fundamentals supposed to affect the exchange rate movements including the real net capital flows (NKF), terms of trade shocks (TOT), government fiscal stance (GOV), foreign reserve level (RES), index of monetary policy (MOP) and relative productivity (PROD) to get it. Using quarterly data from 1980Q1 to 2012Q4, the empirical analysis commences by checking the stationarity of the variables that turn out to be all stationary at first difference. Then, using the cointegration test and the Vector-Error Correction Model of the Moroccan Dirham exchange rate as function of the indicated macroeconomic fundamentals, the regression shows that the main fluctuations of the real effective exchange rate are due to trade openness, government spending, terms of trade, the productivity progress, monetary policy and net capital inflow. Accordingly, and using HP decomposition filter we figure out three periods of under/overvaluation ranging from $2.80 \%$ under to $2.16 \%$ over equilibrium level, furthermore, the misalignment from the equilibrium level needs from five to six years to be eliminated.
\end{abstract}

Keywords: real exchange rate equilibrium, stationarity, cointegration, VECM, BEER, PEERHodrick-Prescott decompositionand Morocco

\section{Introduction}

The Moroccan dirham was pegged to the French franc and followed the same volatility as experienced by the later in early 1970. This regime didn't allow the Moroccan economy to achieve its target in terms of internal and external balances. In 1973, Moroccan authority adopted a managed float regime to a basket of currencies with the Euro and The USD as principal components. In 1980, and as Morocco became heavily indebted, the basket weights got rebalanced for the first time, with a continued restructuration until 2001, when the composition became $80 \%$ for the EURO (the currency of the principal trade partner of Morocco) and 20\% for the American dollar according to the Central Bank of Morocco. The choice of the currency is made according to the relative importance of each trading partner's currency and the Moroccan external settlement currencies. The Moroccan economy is an emerging economy and faces the troubles faced by its emerging neighbours. The economy is based to a great extent on the rain-fed agriculture production and tourism remittances, which makes relatively weak and unstable the economic growth. Other sources of the economic growth in Morocco are the financial stock, and the financial market is considered so far as one of the most active stock markets in Africa but it showed a chequered evolution recently. One of the worry a country can face is to make an arbitrage between low volatility of exchange rate and its misalignment.The exchange rate misalignment is not verified to have palpable implications on macroeconomic fundamentals, however, a consensus associating a reasonable growth and sustainable internal and external balance with equilibrium exchange rate exists, (Edwards, 1989). The literature on the exchange rate has the Purchasing Power Parity as starting point; it stipulates that the exchange rate reflects the movements in the nominal exchange rate given that the real exchange rate is fixed, (Cassel, 1916). Williamson (1994) defined the fundamental Equilibrium Exchange Rate (FEER) as the real effective exchange rate which ensures both internal and external balances simultaneously, with the internal balance being the potential output with a low inflationary level, and the external balance appearing when sustainable balance of payment position coexists with a sustainable external debt level (Williamson, 1994). To overcome this "idealistic" view of the FEER, the Behavioral Equilibrium exchange rate BEER came to showcase the cyclical and 
temporary movements of the real exchange rate based on the current values instead of the values of fundamentals associated with the full employment state.Then, we use the behavioral equilibrium exchange rate defined as a function of a set of macroeconomic variable to get this equilibrium value. This study aims to calculate Morocco's exchange rate misalignment using Behavioral Equilibrium Exchange Rate (BEER) approach and the Vector Error correction Model VECM statistics after that, define the misalignment value and the time required for the exchange rate to regain equilibrium. This paper is structured as follows: (ii) the literature review and the theoretical framework on studies that have applied BEER approach; (iii) data and methodology; (iv) the empirical results along with their interpretations then a brief summary and concluding recommendations.

\section{Literature Review}

\subsection{The Behavioral Equilibrium Exchange Rate Economics Background}

The real exchange rate misalignment is measured as the deviation of actual real exchange rate from its equilibrium value. Many theoretical frameworks have been used to model the effect of macroeconomic fundamentals on the "equilibrium" exchange rate. As mentioned above both external and internal balances are implicated in the equilibrium determination process. However, there are difficulties related to this approach because they mostly deal with a full specification of the multilateral structural model and the casual relationship among variables. The BEER model was put forward by Macdonald (1997) and Clark \& MacDonald (1998) that connect the real exchange rate to fundamentals via the real interest parity. This approach links the real exchange rate to a set of fundamentals through a single equation setting and the set of macroeconomics variables is not predefined by the theory, it's determined on an ad hoc basis. In the case of FEER, the long term values of fundamentals associated with full employment state are used, whereas, observed values currently prevailing in the economy are used in the case of BEER. Simplicity and absence of subjectivity are the main features that make this model an appropriate model to fit the luck of data in developing countries. The BEER model emphasizes the impact of productivity on traded goods sectors and terms of tradeshocks. Besides using fundamental variables, the BEER methodology categorizes the exchange rate to the "current" and the "cyclical" component, the equilibrium exchange rate computed from the observed values of fundamentals (Driver \& Westaway, 2001).

\subsection{Previous Studies Findings}

In the literature, many papers have been written about the equilibrium exchange rate and its determinants using the BEER methodology like Zhang (2001); Bénassy-Quéré et al. (2004) and Shi \& Yu (2005). Baffes et al. (1999) computed misalignment for Côte d'Ivoire and Burkina Faso using single equation time series, Côte d'Ivoire's actual real exchange rate was found to be overvalued by $34 \%$ on average between 1987 and 1993.Iimi (2006) using the BEER approach found the Botswana's currency to be undervalued before 1980s and overvalued by $5 \%$ to $10 \%$ in the recent years. Fatma Marrakchi Charfi (2008) examined the misalignment for the case of Tunisia using the BEER, she found that Tunisian dinar's behaviour in the long-run was influenced by the net capital inflows, terms-of-trade shocks, and the productivity differential. The Tunisian dinar was found to be overvalued before in late 1980s then converged to its equilibrium level over the 1990s' after 1986's devaluation. Shehu Usman Rana (2008) used BEER methodology for Nigeria currency and found the index of crude oil volatility, the real net foreign assets, terms-of- trade shocks, the monetary policy performance and the government fiscal policy to explain the behaviour of Real Effective Exchange rate in the long term and identified four episodes of overvaluation and undervaluation. As for the case of Morocco, Jamal et al. (2004), used non-parametric and nonlinear methods to measure the exchange rate misalignment between 1967 and 2001, they found the exchange rate value in the long run was influenced by the terms-of-trade shocks, trade openness and government spending. Results show that the MAD was undervalued, overvalued then undervalued. The present paper differs from the previousstudies in several aspects: First of all, we use the trade adjusted Real Effective Exchange Rate (REER) instead of the bilateral real exchange rate, widely used in the literature. Secondly, our paper takes into account seven fundamental variables to allow for a better understanding of the exchange rate behaviour. Lastly, this paper aims to cover a wider period in order to avoid the sample size shortage problem. Quarterly data have been used covering the period from 1980Q1 to 2012Q4.

\section{The Empirical Model}

\subsection{Econometric Model}

We specify the REER as a function of a vector of macroeconomic fundamental variables, $\mathrm{F}$, as:

$$
\operatorname{Ln}\left(E R_{t}^{*}\right)=\beta^{\prime} \cdot F_{t}+\varepsilon_{t m}
$$

Or

$$
\text { BEER }=f(G O V, \text { OPEN, NFK, TOT, RSV, MOP, PROD })+\text { Error }
$$


Where $E R^{*}$ is the equilibrium value of the Exchange Rate and $\beta$ is the vector of coefficients for each variable from fundamentals noted $F$. We estimate the vector $\beta$ of the long run level for each fundamental; these permanent values may exhibit a substantial degree of "noise" in the short run only (Baffes, et al 1999). We use Johansen and Juselius (1991) and Johansen (1988) co-integration analysis to detect the long-run relationship between stock price and exchange rates. The cointegration determination requires that series under study have the same order of integration. Therefore, we start our study by checking the stationarity of variables using the Augmented Dickey Fuller (ADF) and Pillips-Perron (PP) tests.

$$
\Delta y_{t}=c+\sum_{i=1}^{K} \tau \Delta y_{t-1}+\prod y_{t-1}+\eta_{t}
$$

Where $y_{t}$ is a vector of non-stationary I(1) variables and $c$ is the constant. The information on the coefficient of Philips-Perron's matrix between the levels of $\Pi=\alpha \beta^{\prime}$ with $\beta^{\prime} y_{t}$ being integrated at level or $\mathrm{I}(0)$. Adjustment coefficients band which are the relevant elements of the matrix are contained in the $\beta$ matrix. To identify the number of cointegration vectors, we use the two likelihood ratio test statistics proposed by Johansen and Juselius (1991). The first parameter is the maximum eigenvalue statistic which is the likelihood ratio statistics for the null hypothesis of exactly $(r)$ cointegrating vectors against the alternative of $(r+1)$ vectors. The second is the trace statistic metric, it tests the hypothesisesof at most ( $\mathrm{r}$ ) cointegrating vectors against the alternative of $(\mathrm{m})$ cointegrating relations, (with $\mathrm{r}=0,1, . . \mathrm{m}-1$ ). We use the H-P filter to decompose each fundamental value into the "long-run" and "permanent" values and separate the trend component from the stationary component.

\subsection{Data Definition}

It is true that that the structure of real exchange rate economics is known. In the present study we are interested in the causality between the exchange rate and selected fundamentals. The empirical study unveils the fundamentals that do affect the REER. In this paper, we utilize the government spending (GOV), Terms of Trade (TOT), Net capital flow (NKF), Monetary policy (MOP), trade openness (OPEN), Reserves (RSV) and productivity differential (PROD). The combination of every variable's change yields new equilibrium level of REER. The variables are used in quarterly basis from 1980Q1 to 2012Q4, and we expect the sign of each variable to be as follow:

$$
\begin{aligned}
& \left(\begin{array}{lllllll}
(-) & (-/+) & (+) & (+) & (+) & (-/+) & (-/+)
\end{array}\right. \\
& \text { REER }=f(G O V, O P E N, P R O D, R E S, M O P, T O T, N K F)
\end{aligned}
$$

All variables are transformed to the natural logarithm to allow the verification of characteristics of partial elasticity in the short and long run and also to work with the hypothesis of variation rate rather than the variables at level. The only variable taken at level is Net Capital Flow since it can have negative or positive value.

The Real EffectiveExchange Rate (REER): The determination of the Real Exchange Rate faces the problem of non availability of data about emerging countries Tradable goods' prices and the difficulty of determination of nontradables prices. For empirical purpose we use the real effective exchange rate of Morocco vis-à-vis its major trading partners following the trade balance. The REER is calculated as a geometric weighted average of bilateral real exchange rates. $S^{M A D}$ and $S^{i}$ are the bilateral exchange rate of MAD and the country i's currency respectively. $C P I^{M A R}$ and $C P I^{i}$ are the consumer price index for Morocco and the consumer price index for country $i$; the weightof the tradepartner country $i$ trade wise is $w$.

$$
\mathrm{REER}=\prod_{\mathrm{i}=1}^{\mathrm{n}}\left[\frac{S^{M A D} \cdot C P I^{M A R}}{S^{i} \cdot C P I^{i}}\right]^{w}
$$

Government spending (gov): GOV is the proxy for the fiscal policy, It's the ratio of government spending to GDP, in the literature, no consensus exists about the impact of the government spending on the REER, since it relies on whether extra funds are channeled toward tradable or non tradable goods; the REER tends to appreciate if nontradables are receiving more and depreciate when tradables receive the extra funds (Dibooglu, 1996) and (Iossifov\&al., 2007). The literature seems to privilege the negative effect of government spending on the REER since, and unlike the private sector, government tends to spend more resources on nontradable sectors than on tradable Baffes et al., (1999) and Mongardini, (1998).

$$
G O V=\frac{\text { General Government Consumption }}{G D P}
$$

Trade Openness (OPEN): is the total of imports and exports to the GDP, what seems to be obvious is that the higher supply of the imported/exported goods induces a drop in the supply of nontradables. In the available 
literature, the impact of commercial liberalization is ambiguous and we can't define the a priori sign of openness factor in the model (Edwards, 1992).

$$
O P E N=\frac{(\text { Imports }+ \text { Exports) }}{G D P}
$$

Net Capital Flows (NKF): Considered as one of the determinants of the REER MacDonald \& al., (2003), The net capital flows can be calculated by deducting the change in ratio of reserves scaled by GDP from the balance of goods and services to GDP ratio, according to the portfolio-balance, either the international financial institutions or foreign capital inflow could finance a deficit in the current account which is the source of increase in the net foreign debt of a country. The sign of NKF depends on the government intervention.

$$
\mathrm{NKF}=\left[-\left(\frac{\text { export-import }}{G D P}\right)\right]-\left(\frac{\Delta \text { Reserve }}{G D P}\right)
$$

Reserves (Res): Corresponds to the ration of total reserve to GDP and it captures the impact of the reserve on the real exchange rate. The magnitude of government interventions determines the sign of the Res variable. If Res is significant this means there is no government intervention.

Terms of Trade Shocks (TOT): Described as the ratio of exports to imports pricewise, (Baffes \& al.,1997), TOT reflects foreign prices a country face, the terms of trade's effect on the RER cannot be obviously derived as it depends on whether the income effect dominates the substitution effect and vice versa. The TOT can't be a priori signed.

Monetary Policy (MoP): To assess the effectiveness of a monetary policy we can refer to the ratio of liquidity to GDP ratio (M2 to GDP). When liquidity ratio increases, price level increases leading to an appreciation of REER (REER value increases). Thus, a positive effect is expected.

Relative productivity (Prod): is calculated as the ratio of labour productivity relative to geometrically weighted foreign labour productivity, where labour productivity is a ratio of GDP relative to the total employment. The weights used follow the same logic as REER determination (trading partner basis). The well known Balassa-Samuelson effect (1983), asserts that in the process of growth tradable goods prices react faster to a real cost reduction than non nontradables, which causes the prices of a currency (priced in local currency) to fall through time as asserted by the product augmenting characteristic (Note 1). So, the sign of (PROD) would be positive which reflects that the increase in PROD leads to REER appreciation.

$$
\mathrm{PROD}=\frac{\text { Labor Productivity }}{\prod(\text { Labor Productivity })^{\mathrm{w}}}=\frac{\frac{G D P}{\text { Total Employment }}}{\prod\left(\frac{G D P}{\text { Total Employment }}\right)^{\mathrm{w}}}
$$

All data is either from Morocco's Finance and Economy ministryor the International Monetary Fund data, IFS. Figures from 1 to 8 below portray the behaviour of our fundamentals from 1980 to the end of the year 2012. 


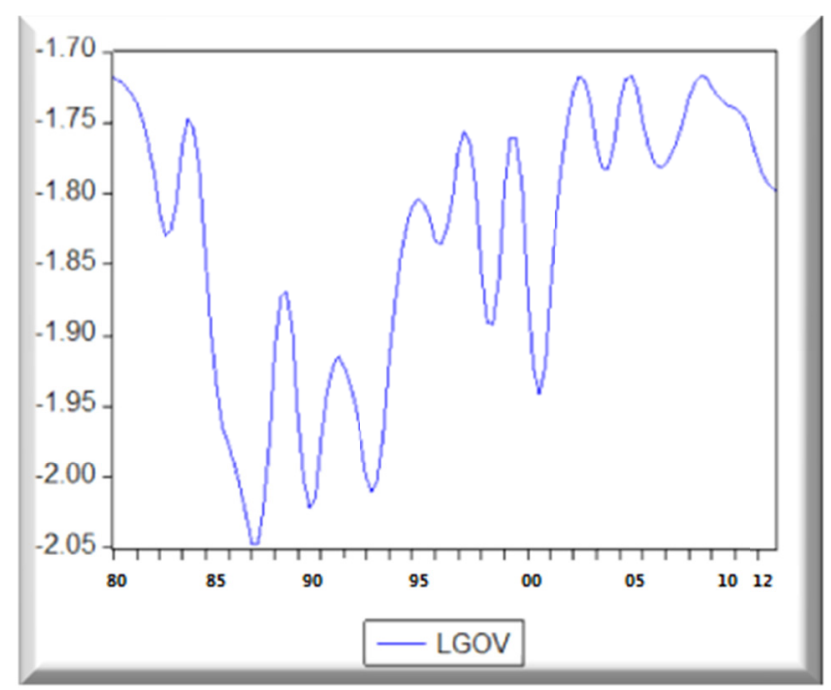

Figure 1. Real effectiveexchange rate

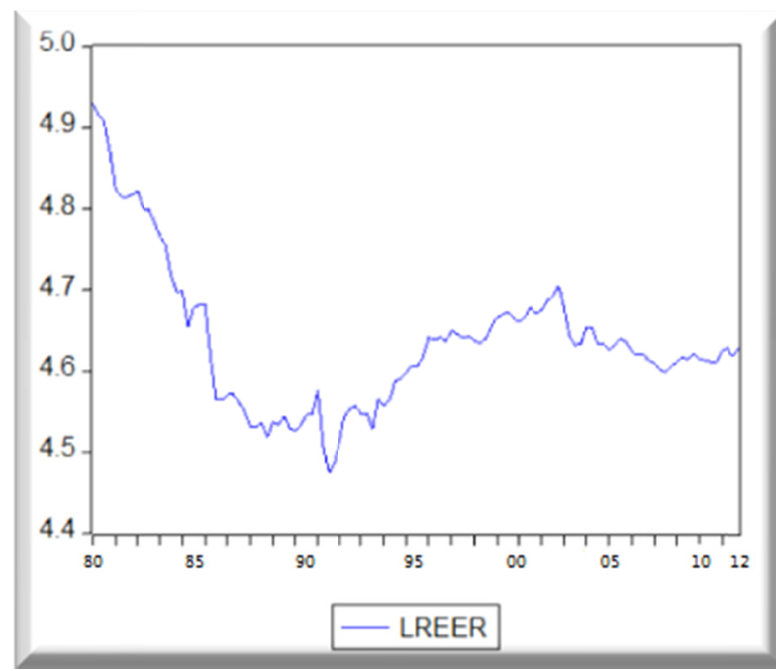

Figure 2. Real effective exchange rate

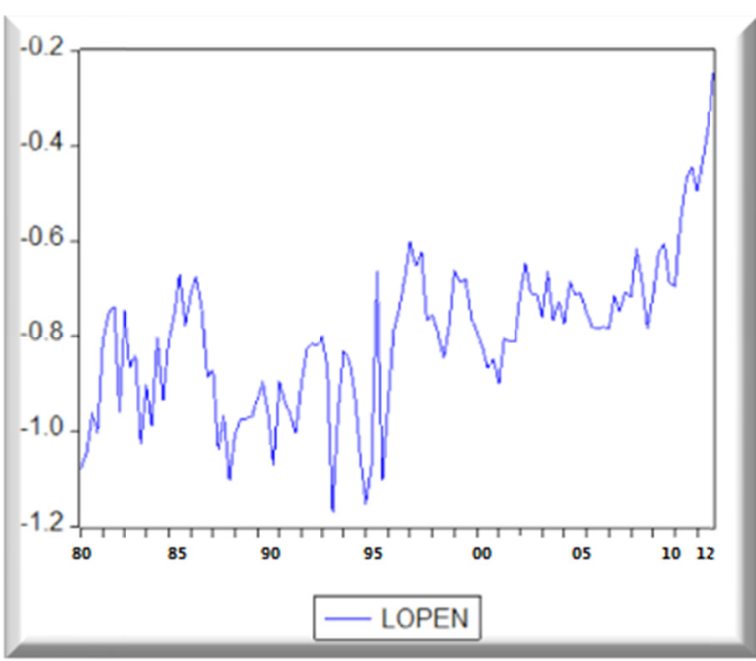

Figure 3. Trade openness 


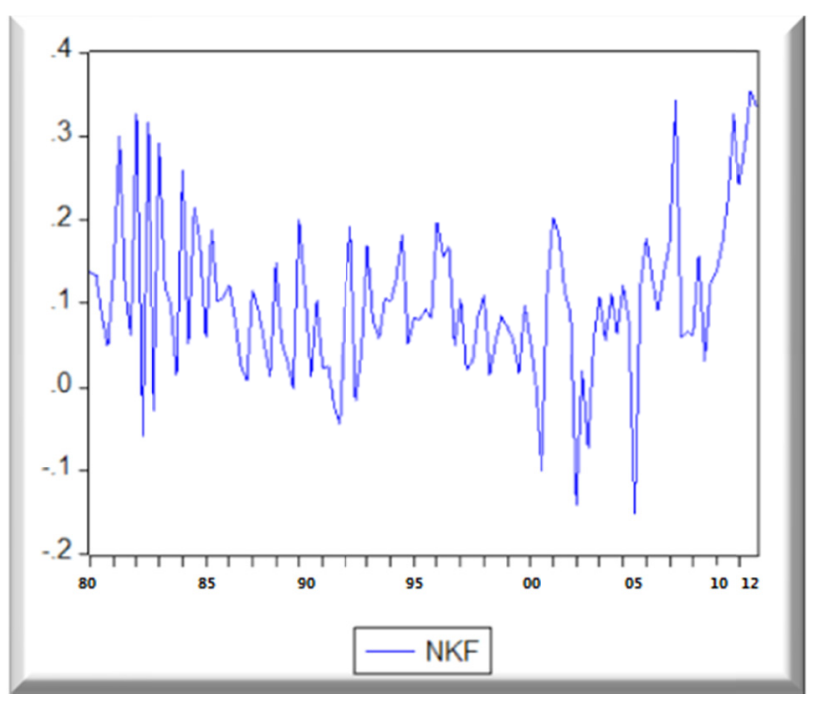

Figure 4. Net capital flows

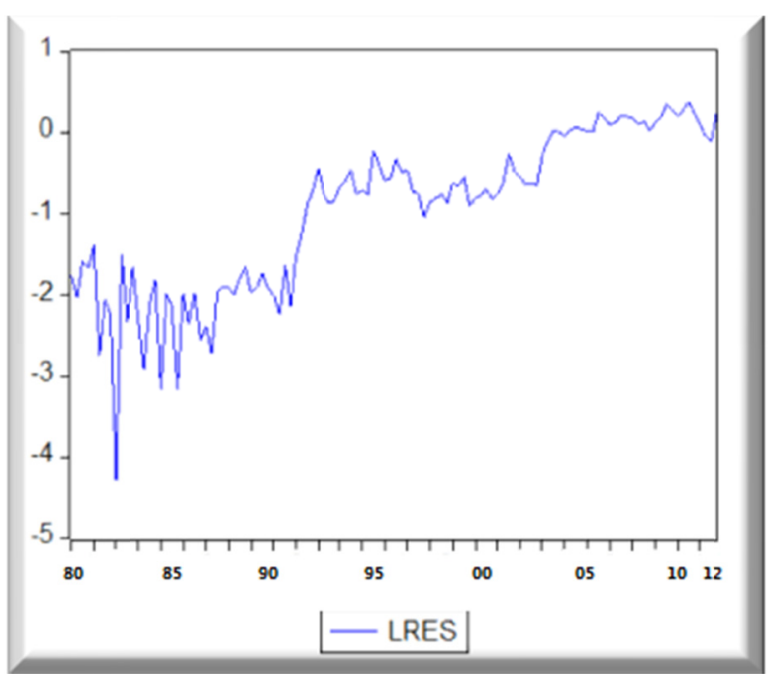

Figure 5. Reserves ratio

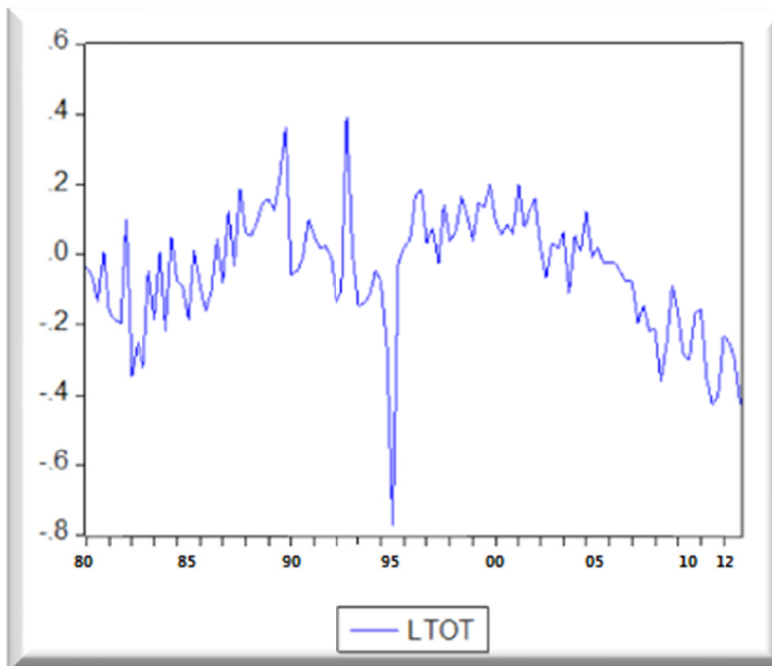

Figure 6. Terms of trade ratio 


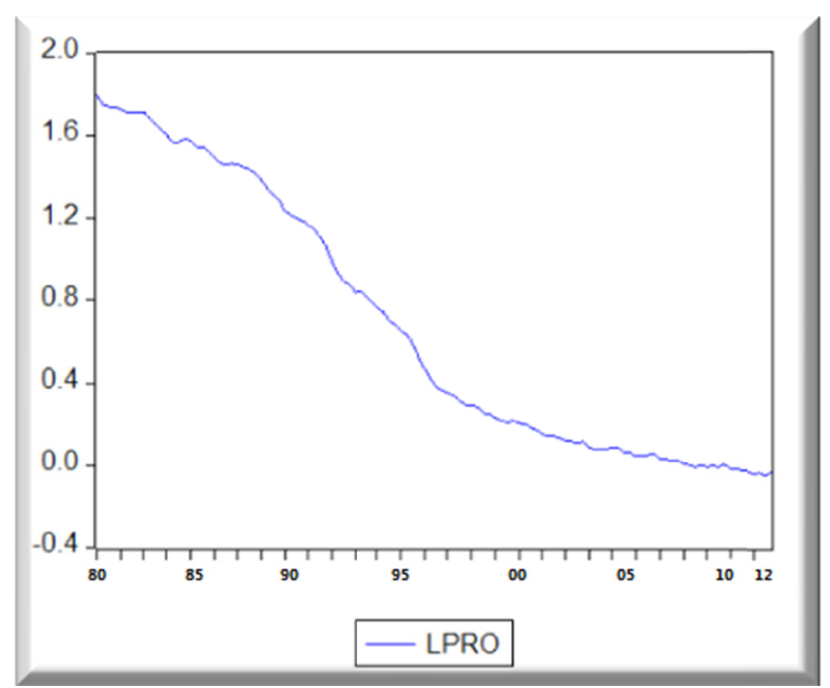

Figure 7. Monetary policy proxy

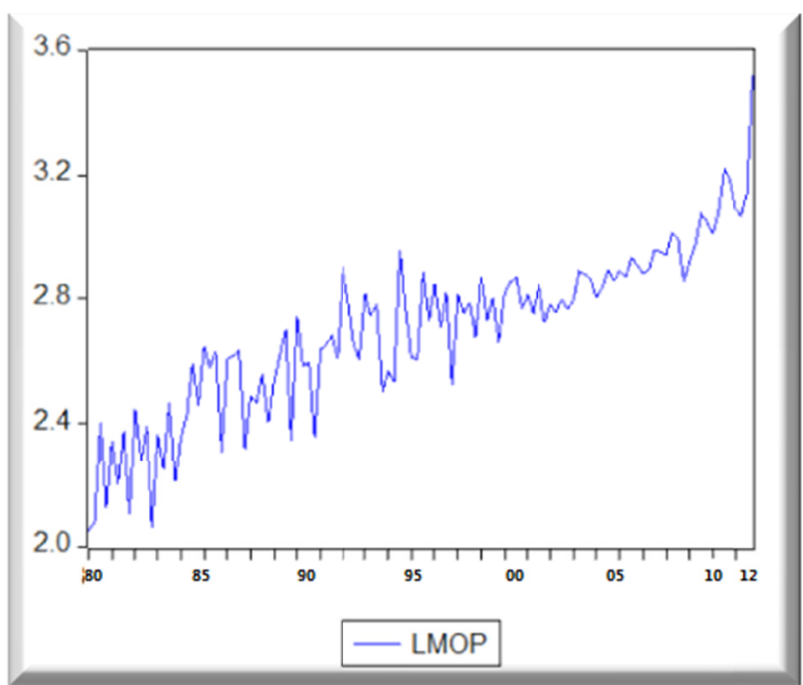

Figure 8. Relative productivity

\section{Results and Discussion}

\subsection{Stationarity Test}

Prior to the model estimation, we check the stationarity of variables by testing for unit root hypothesis against the stationarity alternative the REER and other fundamentals. All variables in quarterly basis were transformed into natural logarithm and tested for stationarity using both the Augmented Dickey-Fuller (ADF) unit-root test (Note 2) and Philis Perron test. Results are reported in Table 1. 
Table 1. Stationarity test for the fundamentals: ADF and PP tests

\begin{tabular}{cccc}
\hline Variable & ADF test & Phillips-Perron & Decision \\
\hline LREER & $\mathrm{I}(1)$, trend & $\mathrm{I}(1)$, intercept & Integrated at first level of difference \\
DLREER & $\mathrm{I}(0)^{*}$, trend & $\mathrm{I}(0)^{*}$, trend & \\
LGOV & $\mathrm{I}(1)$,intercept & $\mathrm{I}(1)^{* *}$ & Integrated at first level difference \\
D(LGOV) & $\mathrm{I}(0)^{*}$, intercept & $\mathrm{I}(0)^{* *}$ & \\
LMOP & $\mathrm{I}(1)$, trend & $\mathrm{I}(1)$, intercept & Integrated at first level difference \\
D(LMOP) & $\mathrm{I}(0)^{*}$ & $\mathrm{I}(0)^{*}$ & \\
LOPEN & $\mathrm{I}(1)$, none & $\mathrm{I}(1)$, none & Integrated at first level difference \\
D(LOPEN $)$ & $\mathrm{I}(0)^{*}$ & $\mathrm{I}(0)^{*}$ & \\
LRES & $\mathrm{I}(1)$, trend & $\mathrm{I}(0)^{* *}$ & Integrated at first level differential \\
D(LRES $)$ & $\mathrm{I}(0)$ & & \\
LTOT & $\mathrm{I}(1)^{* *}$ & $\mathrm{I}(0)^{* *}$ & Integrated at first level differential \\
D(LTOT) & $\mathrm{I}(0)^{*}$ & $\mathrm{I}(0)^{*}$ & \\
NKF & $\mathrm{I}(1)$ & $\mathrm{I}(1)^{*}$ & Integrated at first level differential \\
D(NKF $)$ & $\mathrm{I}(0)$ & $\mathrm{I}(0)^{*}$ & \\
\hline
\end{tabular}

Note: $\left({ }^{*}\right)$ and $(* *)$ denote significance level at $1 \%$ and $5 \%$ respectively.

All combinations with/without intercept and time trend are taken into account and the significance level of each variable determines the final selection of the parameter. According to the ADF test results all variables are not stationary at level, so, we cannot reject the null hypothesis of a unit root in the level series for all variables. In order to achieve stationarity, we differenced our data and run stationarity test again, and the nonstationarity hypothesis is rejected at 99 percent level of confidence rejecting by the same occasion the existence of unit root.We use the cointegration tests to verify the presence of stable and long-term relationships. We use Akaike criterion, Hannan-Quinn (HQ) et Schwarz (SC) (Note 3) to choose the optimal lag, we take 4 lags as our criterion suggests and we use the Johansen's Trace test for the cointegrating rank (Johansen, 1988) with the null hypothesis of no cointegration and the alternative hypothesis being the existence of one or cointegrating vectors. For our case, four cointegrating relationships are found in the system, meaning that 4 unique cointegrating vectors span the cointegrating space. Results are shown in the tables 2 and 3.

Table 2. Johansen test, cointegration rank test (Trace)

Sample (adjusted): 1981Q2-2012Q4. Trend assumption: Linear deterministic trend. Series: Lreer Lpro Lopen Lm2 Lgov Lres Ltot Nkf. Lags interval (in first differences): 1 to 4

\begin{tabular}{ccccl}
\hline $\begin{array}{c}\text { Hypothesized } \\
\text { No. of CE(s) }\end{array}$ & Eigenvalue & $\begin{array}{c}\text { Trace } \\
\text { Statistic }\end{array}$ & $\begin{array}{c}0.05 \\
\text { Critical Value }\end{array}$ & Prob. $^{* *}$ \\
\hline None & 0.464020 & 257.0689 & 159.5297 & 0.0000 \\
At most 1 & 0.445972 & 187.8429 & 125.6154 & 0.0000 \\
At most 2 & 0.345614 & 122.2929 & 95.75366 & 0.0002 \\
At most 3 & 0.244500 & 75.22251 & 69.81889 & 0.0174 \\
At most 4 & 0.188495 & 44.10081 & 47.85613 & 0.1079 \\
At most 5 & 0.114868 & 20.91678 & 29.79707 & 0.3629 \\
At most 6 & 0.063318 & 7.372675 & 15.49471 & 0.5347 \\
At most 7 & 0.001009 & 0.112023 & 3.841466 & 0.7378 \\
\hline
\end{tabular}

Trace test indicates 4 cointegratingeqn(s) at the 0.05 level. * denotes rejection of the hypothesis at the 0.05 level. **MacKinnon-Haug-Michelis (1999) p-values 
Table 3. Johansen test, Cointegration Rank Test (Trace)

Sample (adjusted): 1981Q2-2012Q4. Trend assumption: Linear deterministic trend. Series: LREER LPRO LOPEN LM2 LGOV LRES LTOT NKF. Lags interval (in first differences): 1 to 4

Unrestricted Cointegration Rank Test (Maximum Eigenvalue)

\begin{tabular}{|c|c|c|c|c|}
\hline $\begin{array}{l}\text { Hypothesized } \\
\text { No. of CE(s) }\end{array}$ & Eigenvalue & $\begin{array}{c}\text { Max-Eigen } \\
\text { Statistic }\end{array}$ & $\begin{array}{c}0.05 \\
\text { Critical Value }\end{array}$ & Prob.** \\
\hline None $^{*}$ & 0.464020 & 69.22600 & 52.36261 & 0.0004 \\
\hline At most $1^{*}$ & 0.445972 & 65.54996 & 46.23142 & 0.0002 \\
\hline At most $2^{*}$ & 0.345614 & 47.07041 & 40.07757 & 0.0070 \\
\hline At most 3 & 0.244500 & 31.12170 & 33.87687 & 0.1030 \\
\hline At most 4 & 0.188495 & 23.18403 & 27.58434 & 0.1658 \\
\hline At most 5 & 0.114868 & 13.54411 & 21.13162 & 0.4035 \\
\hline At most 6 & 0.063318 & 7.260652 & 14.26460 & 0.4588 \\
\hline At most 7 & 0.001009 & 0.112023 & 3.841466 & 0.7378 \\
\hline
\end{tabular}

Note: Max-eigenvalue test indicates 3 cointegratingeqn(s) at the 0.05 level. ${ }^{*}$ denotes rejection of the hypothesis at the 0.05 level. ${ }^{* *}$ MacKinnon-Haug-Michelis (1999) p-values.

We select the first cointegrating equation to represent the long-run relationship between real exchange rate and selected fundamental variables. Coefficients of the long run behavioral cointegration model are presented in Table 4.

Table 4. Vector error correction estimates, at level in the long run

\begin{tabular}{cc}
\hline & Vector Error Correction Estimates \\
Variables & Vector Coefficients () \\
\hline LREER(-1) & 1.000000 \\
LGOV(-1) & -0.924030 \\
& $(0.17933)[5.15274]$ \\
LMOP(-1) & 1.520209 \\
& $(0.14228)[10.6845]$ \\
LOPEN(-1) & -0.591531 \\
& $(0.10815)[-5.46957]$ \\
LPRO(-1) & 0.335317 \\
& $(0.05293)[6.33523]$ \\
LRES(-1) & -0.070724 \\
& $(0.02622)[-2.69775]$ \\
LTOT(-1) & 0.469261 \\
& $(0.08128)[5.77328]$ \\
NKF(-1) & 0.150729 \\
C & $(0.16508)[0.91308]$ \\
\hline
\end{tabular}

Note: Standard errors in ( ) \& t-statistics in [ ]. The t statistics significant at $5 \%$ and $10 \%$ levels of significance are indicatedby $*$ and $* *$ respectively.

These coefficients catch the effect of each fundament's behaviour in the exchange model, according to our estimated results of the cointegrating vectors $\beta$ the long-run equilibrium equation can be written as:

$\begin{array}{ccccc}\text { LREER }= & -0.924030 \mathrm{LGOVR}+ & 1.520209 \mathrm{LMOP}- & 0.591531 \mathrm{LOPEN}+ & 0.039711 \mathrm{LPRO}- \\ (-5.15274) & (-10.6845) & (-5.46957) & (-6.33523) \\ 0.070724 \mathrm{RES}+ & 0.469261 \mathrm{LTOT}+ & 0.150729 \mathrm{NKF} & \\ (-2.69775) & (-5.77328) & (-0.91308) & \end{array}$

As we may notice in the table 5 , except the NKF, all variables are statistically significant. Most coefficients are correctly signed based on the hypothesis formulated previously. The spending of the government is rather channelled towards tradablesso it weakens the confidence in the currency leading to a depreciation of 
the exchange rate. This is, however, not in contradiction with the fact that an increase in government consumption pushes the nontradables sector demand up leading to a higher national productivity, and participates in conserving foreign exchange and improves real exchange rate. As Morocco's economy is still growing, this condition may be violated given the inefficiency in capacity utilization and the increasing level of energy consumption and other operating costsin the nontradable sector. Statistically and economically signed, our proxy for the monetary policy exerts a positive relationship between REER and the liquidity level in the Moroccan economy; the increase in liquidity ratio increases the general level of prices and leads to an appreciation of REER asspecified in our framework. The TOT has positive sign suggesting a domination of positive income effect. The reserve to GDP ratio (RES) impacts positively the REER and the coefficient of relative productivity PROD is consistent with economic theory with a positive impact on REER. The negative effect of trade openness (OPEN) on the long run REER appears when the rise of openness degree reduces the support to import competing industries and nontrables sector gets the biggest portion of resources, which induces to a depreciation of exchange rate. We conclude then that the degree of openness affects negatively the real effective exchange rate in the long run.

\subsection{VECM Results and Misalignment}

The presence of cointegration relationship denotes the existence of a vector error correction mechanism (VECM). This model links the short run movement of the real exchange rate and Changes in the fundamentals in a given period of time. The relationship is identified between variables at the same period (in the short run) and the correction term is related to the previous period. The error correction term is computed as the gap between the observed real exchange rate and the computed rate "fitted" by the fundamentals at leveland the calculated coefficients. Clearly, this error correction term predicted by fundamentals is a crucial element in the self-correction mechanism of the real exchange rate to converge to the long run value estimated according to the observed values of the fundamentals. The VEC Model is then build up with the short run fundamentals of the real exchange rate, Table 5 summarizes results of the estimation of four different specifications of the VECM.

Table 5. Vector error correction estimates, after the first difference in the short run

\begin{tabular}{cc}
\hline Variables & Adjustment coefficients \\
\hline $\mathrm{D}($ LGOV $)$ & $0.04073^{*}$ \\
& $(-0.01344)[3.03087]$ \\
$\mathrm{D}(\mathrm{LMOP}) \mathrm{S}$ & 0.053145 \\
& $(-0.10913)[0.48700]$ \\
$\mathrm{D}($ LOPEN $)$ & $0.216101^{*}$ \\
& $(-0.10107)[2.13806]$ \\
$\mathrm{D}(\mathrm{LPRO})$ & $0.05137^{*}$ \\
& $(-0.01549)[3.31738]$ \\
$\mathrm{D}(\mathrm{LRES})$ & $-1.28902^{*}$ \\
$\mathrm{D}(\mathrm{LTOT})$ & $-0.42682)[-3.02002]$ \\
& $(-0.1474)\left[-2.009449^{*}\right.$ \\
$\mathrm{D}(\mathrm{NKF})$ & 0.132633 \\
& $(-0.1008)[1.31580]$ \\
\hline
\end{tabular}

Note: Standard errors in ( ) \& t-statistics in [ ]. The t statistics significant at $5 \%$ and $10 \%$ levels of significance are indicatedby * and ** respectively.

For the short run, the results show that the real exchange rate is influenced by reserve level, terms of trade, the degree of openness, the productivity differential and the government spending. These results support our findings for the net capital flows which have no effect on exchange rate change in the long run as in the short run. The monetary policy seems to have no effect on the exchange rate change in the short run even though it turned out to be highly significant in the long run, that seems to be logical since a monetary policy needs a longtime to bear fruits.

The coefficients in the VECM identify the average number of times required for a given shock to be corrected in the model. This is calculated as $(1-\alpha)^{t}$, with $t$ being the number of years and $\alpha$ is the adjustment parameter. We reported the speed adjustment component of the VECM which are the model's coefficients; three out of the four coefficients were correctly signed and statistically significant. For our case, divergences from the equilibrium 
path need four to five years to be eliminated. Later on, we derive the consistent long run equilibrium value for the REER by applying the long run elasticities resuls from the VECM coefficients to the actual values of the macroeconomic fundamentals. Graphically, a misalignment could be declared when the residual's value, in a given time, is different than zero; that could distinctly be seen from the residual graph. The high variability of residuals could distinctly be seen from Figure 9 and figure 10, and we can conclude that the MAD equilibrium is unsustainable. Figure 9 and figure 10 show the BEER and the BEER's residual.

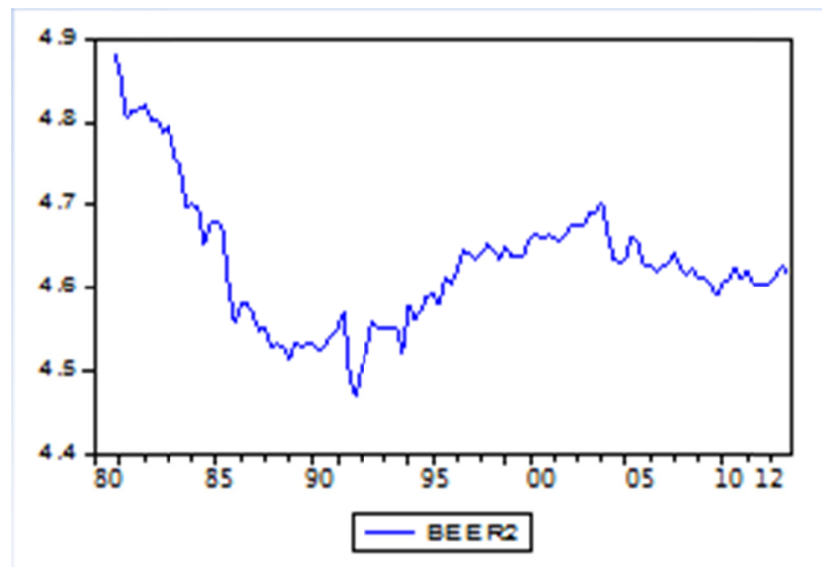

Figure 9. Behavioral equilibrium exchange

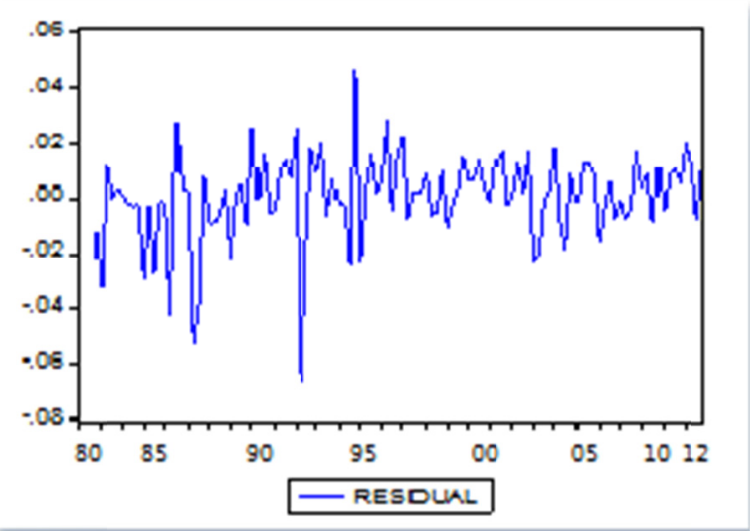

Figure 10. Residual from the BEER rate

The combination of the variables influencing the long run REER (Gov, TOT, OPEN, MOP and PROD) yields the equilibrium values of each period. Next, we use HP filter to smooth out the BEER equilibrium by removing the short-term variations from the explanatory variables to obtain the permanent equilibrium exchange rate (PEER) reported in Figure 11 and figure 12 andas for the PEER it appears to be less volatile than BEER. The cyclical values are calculated by subtracting the permanent values from the REER given as:

$$
\text { Misalignment }=[(\text { REER }- \text { PEER }) / P E E R] * 100
$$




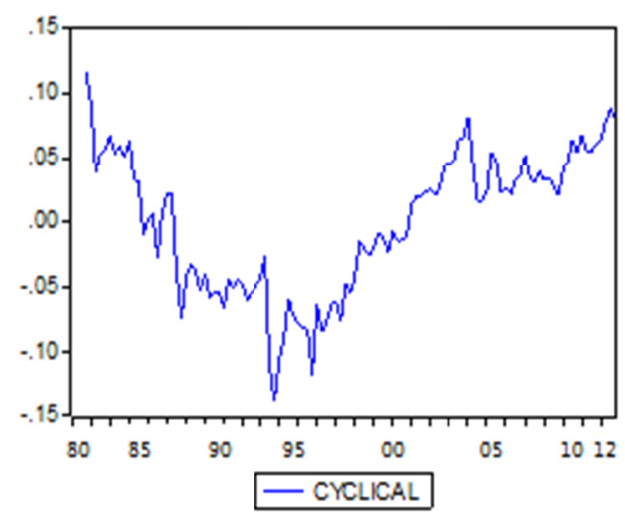

Figure 11. Permanent equilibrium exchange

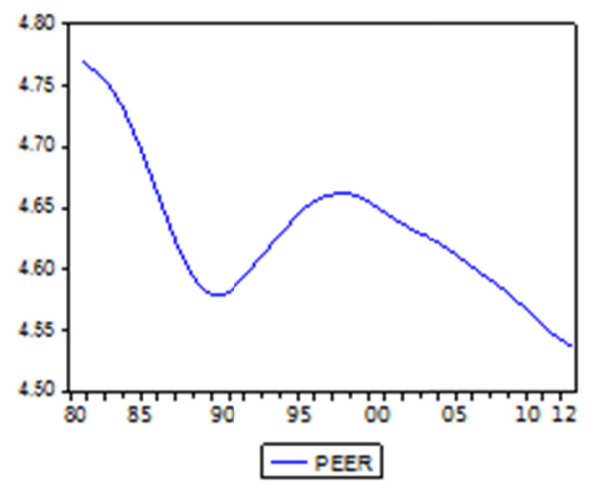

Figure 12. Cyclical shocks of exchange rate

The three series (REER, PEER, BEER), and misalignment are presented together in the figure 13. The range of misalignment lies between 2.16 per cent to -2.80 per cent. When the misalignment is greater/less than zero it means the REER is over/under valuated. We notice that the BEER goes in line with the REER. Three mains periods of over/undervaluation can be detected: From 1980 to 1985, Morocco dirham experienced a clear overvaluation; here we consider the managed peg set up by the Moroccan government in September 1980 in order to allow for the influence of trading partners and different currencies used for the external settlements. This period was characterized by progressive liberalization and aimed to stabilize the internal and external financial situation in Morocco. The year 1983 witnessed the introduction of the Structural Adjustment Program; followed by a general policy aiming to reduce the MAD value to meet the cruel competition Moroccan exports were faces. The Moroccan dirham was devaluated by $9.3 \%$ to overcome the increase of import prices and in order to stabilize the balance of payment position, these movements were accelerated during the eighties till the nineties. The $3^{\text {rd }}$ sequence of misalignment started in 1997 where the MAD depreciation was reversed up to $2.12 \%$ nominal overvaluation of the dirham in April 2001, and reversed to some extent the exchange rate appreciation experienced in the early 1990s. After the devaluation, the REER of the MAD kept the depreciation pace because of the low inflation level in Morocco's commodities prices vis-à-vis trading partners, the period that knew appreciation of the Euro relative to the dollar. Followed in 2001 by the change of the design of currency basket by the Moroccan government which reduces the proportion of dollar and increase the weight of Euro, the REER converged gradually toward the equilibrium level later on. 


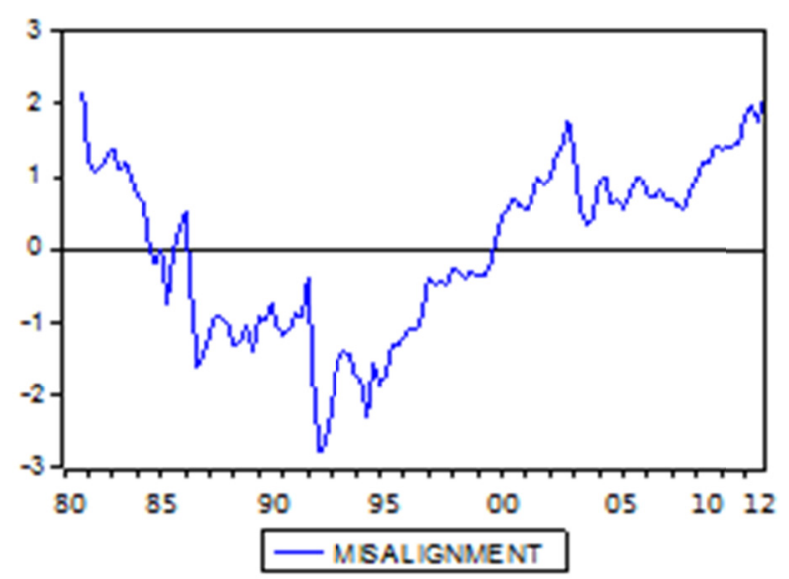

Figure 13. Effective exchange rate

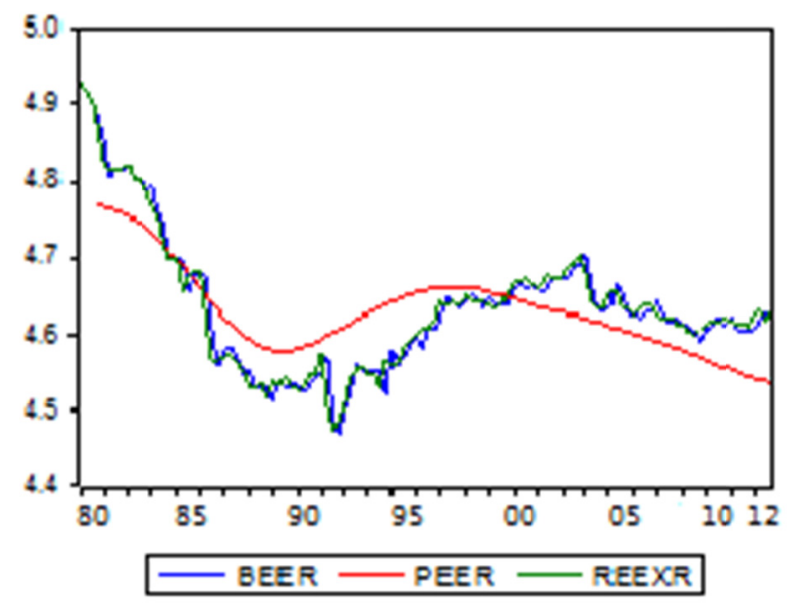

Figure 14. Effective exchange rate misalignment

\section{Conclusion \& Recommendations}

This paper employed a purely statistical and behavioral approach in attempt to analyze the misalignment of the real exchange rate of the Moroccan currency. The equilibrium exchange rate was identified using the behavioral model of the equilibrium exchange rate, and the sustainable component of the behaviral deviation was separated from the cyclical component. The stationarity of Time series of selected variables was tested using the ADF\&PP tests, allseries didn't satisfy the stationarity condition at level, but the hypothesis of the unit root was rejected at 1 percent after the first difference. Four long term cointegrating equations were revealed at 5 percent level of significance using both the trace and the eigenvalue statistics of the Johansen cointegration test. Besides the behavioral model this paper utilized the Johansen's Vector Error Correctionapproach to estimatethe short run behavioral equilibrium of real exchange rate of the Moroccan Dirham between the first quarter of 1980 and the last quarter of 2012 using the appropriate macroeconomic fundamentals. Six out of seven variables turned out to have significant effect on the MAD movement in the long run: trade openness, government spending, terms of trade, productivity progress, net capital inflow, foreign currency reserve level and the monetary policy. It makes sense that the latter's impact doesn't show up in the short run, because the short run is not enough for the monetary policy to have effect.We would like to shed light on one of the important findings, the importance of government spending, trade openness, terms of trade monetary policy, productivity differential and reservesas determinant of the exchange rate. The unsustainability of the Moroccan economy's income which depends on touristic and agricultural activities, these traditional sources should be diversified in order to cover othersources such as a portfolio investment diversification, and the effective utilization of foreign exchange earnings. Using 
HP decomposition filter, permanent (PEER) and cyclical values were determined, we figure out 3 periods of under/overvaluation ranging from $2.80 \%$ under to $2.16 \%$ over equilibrium level, furthermore, the misalignment from the equilibrium level needs from 5 to 6 years to be eliminated. Finally, the plausibility of an empirical study's finding makes its relevancy. We propose the rationalization of the fiscal policy and the fiscal spending. The domestic monetary policy promotion requires a stable and sustainable macroeconomic environment and. A further study might incorporate the effect of the financial market on the exchange rate and the economic development as whole.

\section{References}

Baffes, J., Elbadawi, I., \& O'Connell, S. (1999). Single-equation estimation of the equilibrium real exchange rate. World Bank, Policy Research Department, Washington, DC. http://dx.doi.org/10.1596/1813-9450-1800

Balassa, B. (1964). The purchasing power parity doctrine: A reappraisal. Journal of Political Economy, 72, 584 596. http://dx.doi.org/10.1086/258965

Bénassy-Quéré, A., Lahrèche-Révil, A., \& Mignon, V. (2011). World-consistent equilibrium exchange rates. Journal of the Japanese and International Economy, 25(2), 12-32. http://dx.doi.org/10.1016/j.jjie.2009.02.001

Bouoiyour, J., Emonnot, C., \& Rey, S. (2004). Choix du régime de change dans un paysemergent, le cas du Maroc. Université de Pau et des pays de l'Adour: Mimeo CATT.

Bouoiyour, J., Marimoutou, V., \& Rey, S. (2004). Taux de change réel d'équilibre et politique de change au Maroc: Une approche nonparamétrique. Economie Internationale, 81-104.

Cassel, G. (1916). The present situation of foreign exchange. Economic Journal, 26, 62-65. http://dx.doi.org/10.2307/2222038

Charfi, F. M. (2008). Equilibrium real exchange rate and misalignments: Lessons from a VAR-ECM model applied to Tunisia. Panoeconomicus, 55(4), 439-464. http://dx.doi.org/10.2298/PAN0804439C

Chinn, M. D. (1999). Measuring misalignment: PPP and East Asian currencies in the 1990s. International Monetary Fund, IMF Working Paper WP/99/120.

Clark, P. B., \& Macdonald, R. (2000). Filtering the BEER: A permanent and transitory decomposition. IMF Working Paper, 144.

Clark, P., \& MacDonald, R. (1998). Exchange rates and economic fundamentals: A methodological comparison of BEERs and FEERs. IMF Working Paper WP98/67, Washington: International Monetary Fund.

Dibooglu, S. (1996). Real disturbances, relative prices and purchasing power parity. Journal of Macroeconomics, 18, 69-87. http://dx.doi.org/10.1016/S0164-0704(96)80004-8

Dickey, D. A., \& Fuller, W. A. (1981). Likelihood ratio statistics for autoregressive time series with a Unit Root. Econometrica, 49(4), 1057-1072. http://dx.doi.org/10.1177/053331648201500119

Domaç, I., \& Shabsigh, G. (1999). Real exchange rate behavior and economic growth evidence from Egypt, Jordan, Morocco, and Tunisia. IMF Working Paper, No. 99/40.

Driver, R., \& Westaway, P. F. (2004). Concepts of equilibrium exchange rates. Working Paper 248, Bank of England.

Edwards, S. (1989). Real exchange rates, devaluation, and adjustment: Exchange rate policy in developing countries. Cambridge, Massachusetts: MIT Press.

Engle, R. F., \& Granger, C. W. J. (1987). Co-integration and error correction: Representation, estimation, and testing. Econometrica, 55, 251-276. http://dx.doi.org/10.2307/1913236

Gujarati, D. N. (2003). Basic econometrics (4th ed.). New York: McGraw-Hill.

Hamilton, J. D. (1994). Times series analysis. Princeton NJ: Princeton University Presse.

Hinkle, L. E., \& Montiel, P. J. (1999). Exchange rate misalignment: Concepts and measurement for developing countries. World Bank Research Publication.

Iimi, A. (2006). Exchange rate misalignment: An application of the behavioral equilibrium exchange rate (BEER) to Botswana. IMF Working Paper WP/06/140, Washington: International Monetary Fund.

Iossifov, P., \& Loukoianova, E. (2007). Estimation of a behavioral equilibrium exchange ratemodel for Ghana. IMF Working Paper WP/07/155, Washington: International Monetary Fund. 
Johansen, S. (1988). Statistical analysis of cointegrating vectors. Journal of Economic Dynamics and Control, 12(231), 54.

Johansen, S. (1991). Estimation and hypothesis testing of cointegration vectors in Gaussian vector autore gressive models. Econometrica, 59(6), 1551-80. http://dx.doi.org/10.2307/2938278

Joly, H., Prigent, C., \& Sobczak, N. (1996). Le taux de change réel d'équilibre. Une introduction. Économie et Prévision, 123-130.

MacDonald, R. (1997). What determines real exchange rates? The long and short of it. IMF Working Paper WP/97/21, Washington: International Monetary Fund.

Meese, R., \& Rogoff, K. (1983). Empirical exchange rate models of the seventies: Do they fit out of sample? Journal of International Economics, 14, 3-24. http://dx.doi.org/10.1016/0022-1996(83)90017-X

Mongardini, J. (1998). Estimating Egypt's equilibrium real exchange rate. IMF Working Paper 98/5. http://dx.doi.org/10.1093/biomet/75.2.335

Phillips, B. C. P. (1987). Time series regressions with a unit root. Econometrica, 55(2), 277-301.

Phillips, P. C. B., \& Perron, P. (1988). Testing for a unit root in time series regression. Biometrika, 75, 335-346.

Shi, J., \& Yu, H. (2005). Renminbi equilibrium exchange rate and China's exchange ratemisalignment: 19912004. CCER Working Papers, China Centre for Economic Research.

Williamson, J. (1994). Estimating equilibrium exchange rates.

Zhang, X. (2002). Equilibrium and misalignment: An assessment of the RMB exchange ratefrom 1978-1999. Working Paper No.127, Stanford University.

Zhang, Z. (2001). Real exchange rate misalignment in China: An empirical investigation. Journal of Comparative Economics, 29, 80-94. http://dx.doi.org/10.1006/jcec.2000.1705

\section{Notes}

Note 1. With a given exchange rate, the prices oftradable in Moroccan Dirham and prices in dollars will move together, andthe GDP along with the consumer price index will rise.

Note 2. See Dickey, D.A. \& Fuller, W.A. (1981).Likelihood ratio statistics for autoregressive time series with a Unit Root, Econometrica, 49(4), 1057-1072.

Note 3. Many other methodologies can be used to determine the number of optimal lags to consider, such as Likelihood ratio (LR), and Godfrey-Portmanteau (GP) test. Hamilton James D. (1994), Times Series Analysis, Princeton University Presse, Princeton NJ, 296-98 \& 429-30.

\section{Copyrights}

Copyright for this article is retained by the author(s), with first publication rights granted to the journal.

This is an open-access article distributed under the terms and conditions of the Creative Commons Attribution license (http://creativecommons.org/licenses/by/3.0/). 